\title{
Serum Complement Levels in Infancy: Age Related Changes
}

\author{
CHARLES A. DAVIS, ENRIQUE H. VALLOTA, AND JUDITH FORRISTAL \\ The Children's Hospital Research Foundation and the Department of Pediatrics, University of Cincinnati College of \\ Medicine, Cincinnati, Ohio, USA
}

\section{Summary}

Levels of eight complement components and two control proteins, were determined on cord serum from normal full term neonates and serum from healthy infants aged 1 and 6 months. For all proteins, the levels were below the adult normal at birth and rose toward the adult range by age 6 months. In a second group of 271 patients, ages 1-36 months, serum Clq and properdin levels were measured. For both proteins, the mean values in early infancy were more than two SD below the adult range and did not reach the adult range until 18-21 months of age. The Clq concentration was more variable than that for any other component studied. In infants from 11 months-3 yr of age, Clq levels correlated with serum IgG levels, but properdin levels did not.

\section{Speculation}

Low serum complement levels in neonates may contribute to their increased susceptibility to infections. Correlations between synthetic rates of $\mathrm{Clq}$ and IgG is suggested as the mechanism responsible for the correlation in serum levels of these proteins after age $1 \mathrm{yr}$.

Complement is one of the humoral effectors necessary to integrate an immunologically competent organism $(9,16)$. As a functional unit, it participates in antibody dependent and antibody independent immune reactions as a first line effector of the immune response. The study of clinical syndromes associated with genetic defects of individual complement components $(1,2)$ has helped to elucidate the variety of ways in which complement participates in immunologic defense mechanisms. Neonates and infants have been shown to have relative deficiencies of some of the components of the complement system $(3,5,6,11,16,17,19)$. In order to confirm the results showing low levels of serum complement in infancy and expand them to include a more complete evaluation of the complement profile, the serum levels of $\mathrm{Clq}, \mathrm{C} 2, \mathrm{C} 3, \mathrm{C} 4, \mathrm{C} 5, \mathrm{C} 6$, factor $\mathrm{B}$, properdin, $\mathrm{C} 3 \mathrm{~b}$ inactivator (C3bINA), and $\beta 1 \mathrm{H}$ were measured on neonates and on infants aged 1 and 6 months and compared to normal adult levels. In addition, the maturation of the complement pathway was examined by measuring serum $\mathrm{Clq}$ and properdin levels beginning at age 1 month and extending through age 35 months.

Decreased serum Clq levels found in individuals with hypogammaglobulinemia of various etiologies $(8,12,13)$ are thought by some to reflect either decreased synthesis $(8,11)$ and by others, increased catabolism (13) of this protein. The levels of $\mathrm{Clq}$ in infancy may, therefore, reflect both the maturation of the complement system and the serum IgG level. In order to help separate these influences, the correlations between serum IgG and Clq and, as a control, between IgG and properdin levels were analyzed for infants between 1 and 35 months of age.

\section{MATERIALS AND METHODS}

Serum was obtained prospectively with parental consent from cord blood of 10 normal full term neonates and from 20 normal infants. Ten of the infants were age 1 month, and 10, age 6 months. Specimens were also obtained from 50 normal adults. Complement components were measured on fresh serum or after storage at $-70^{\circ} \mathrm{C}$. Measurement of serum levels of $\mathrm{Clq}, \mathrm{C} 2, \mathrm{C} 3$, $\mathrm{C} 4, \mathrm{C} 5, \mathrm{C} 6$, factor $\mathrm{B}, \mathrm{C} 3 \mathrm{bINA}$, properdin, and $\beta 1 \mathrm{H}$ was by radial immunodiffusion using monospecific antisera made in this laboratory $(7,15,20)$.

In addition, the results of automated immune precipitation (AIP) analysis (4) of serum samples submitted to the laboratory of the Children's Hospital from March, 1975 through July, 1976 were reviewed. Serum from 271 patients whose ages ranged from 1 through 35 months in whom AIP analysis revealed normal levels for age of $\operatorname{IgG}, \operatorname{IgA}, \operatorname{IgM}, \mathrm{C} 3, \mathrm{C4}$, haptoglobin, and albumin were selected for analysis of Clq and properdin levels. The norms used for $\mathrm{C} 3$ and $\mathrm{C} 4$ levels were those established by the prospective study above. These serum specimens were stored at $-20^{\circ} \mathrm{C}$ until use. For purposes of data analysis, patients were grouped according to age; i.e., age 1 month $=$ age 30-60 days.

\section{RESULTS}

COMPLEMENT PROFILES OBTAINED PROSPECTIVELY ON CORD SERUM AND ON THE SERUM OF INFANTS AGES I AND 6 MONTHS

As indicated in Table 1, the complement components measured in cord serum had mean levels ranging from $49-76 \%$ of the adult means. By age 1 month, the levels of most components had risen somewhat, but a few remained the same. Only in the case of $\mathrm{Clq}$ was the mean level significantly lower than that in cord serum. $\mathrm{C} 2$, whose concentration was relatively highest in cord serum was the only component to reach normal adult levels by age one month. At 6 months of age, C2, C4, C5, C6, and factor B had mean concentrations not significantly different from the adult means, whereas the mean concentrations of the remaining complement components and control proteins, Clq, C3, properdin, C3bINA, and $\beta 1 \mathrm{H}$, remained below those for adults. As indicated by the ranges of values, the complement levels from some individuals were within two SD of the adult means at all the ages studied.

\section{RETROSPECTIVE ANALYSIS OF SERUM CLQ AND PROPERDIN LEVELS IN INFANCY}

Clq levels in serum specimens submitted for AIP analysis from 271 infants aged 1-35 months are shown in Figure 1. Serum properdin levels are shown in Figure 2. The mean serum properdin levels at ages 1 and 6 months and the mean serum Clq level at 6 months in these infants are in good agreement with those found in infants at these ages in the prospective study. However, the mean Clq level at age 1 month was significantly greater in the 


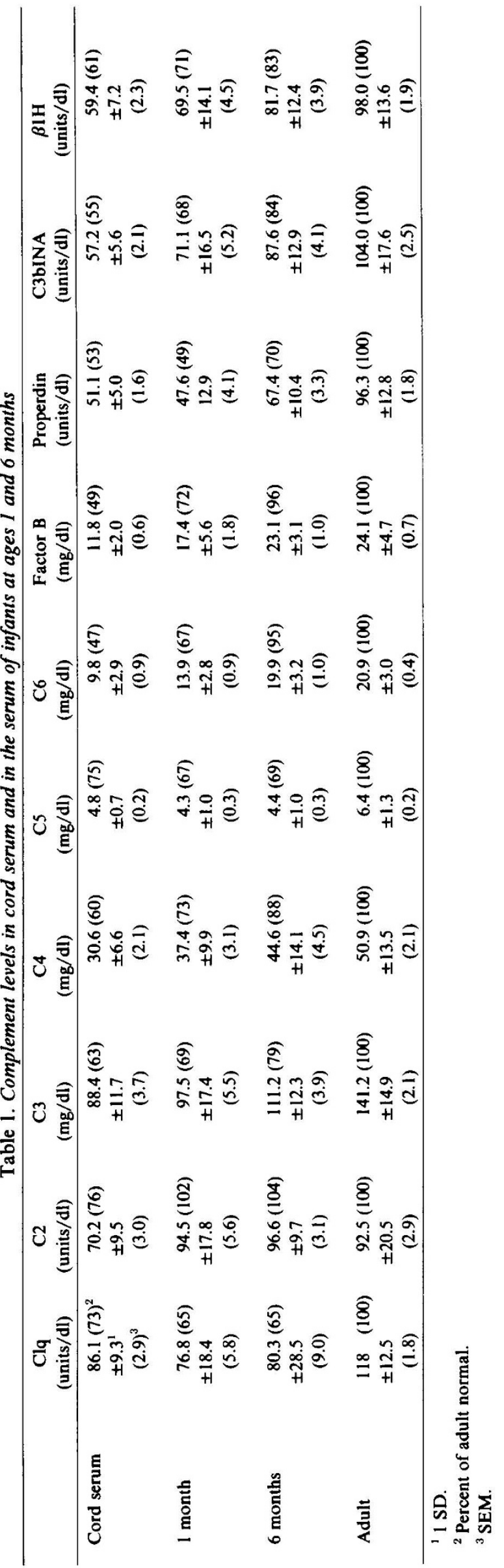

infants studied retrospectively than in those studied prospectively. The reason for this discrepancy is not clear. Of note was the wide range of $\mathrm{Clq}$ values seen in both the prospectively (Table 1) and the retrospectively (Figure 1) obtained sera. The range was considerably wider than that of any of the other components.

The rates of rise of mean $\mathrm{Clq}$ and properdin values were similar, with both remaining more than 1 SD below the adult mean in the first 12 months of life and rising to within $1 \mathrm{SD}$ thereafter. However, $\mathrm{Clq}$ values, with their wider range, showed considerable overlap with adult values at all ages; properdin levels were relatively much lower as compared to the adult range. Between the ages of 24-35 months the mean Clq level remained significantly $(P<0.01)$ below the adult mean whereas the mean serum properdin level did not differ significantly from the normal adult level $(P>0.1)$.

\section{CORRELATIONS BETWEEN IGG AND CLQ LEVELS AND IGG AND PROPERDIN LEVELS}

The correlations between IgG and $\mathrm{Clq}$ and $\mathrm{IgG}$ and properdin for infants were analyzed using the age groupings and patient data given in Figures 1 and 2. Significant correlations $(P<0.05)$ between Clq and IgG were found in infants aged 11 months and persisted in five of the six groups of infants between ages 11 and 35 months of age. Significant correlations between $\mathrm{Clq}$ and $\mathrm{IgG}$ were not found in infants less than 11 months of age. At no age was a significant correlation between the serum IgG and properdin level found.

\section{DISCUSSION}

The levels of complement in cord serum as compared to normal adult levels as found in the present study and by others are summarized in Table 2. Our findings of low levels of Clq, C2, C3, $\mathrm{C4}, \mathrm{C} 5, \mathrm{C} 6$, and factor B are in general agreement with those previously reported. Only Sawyer et al. (17) have reported levels of complement components in cord blood equal to or higher than adult levels. It should be noted, however, that 4 of the 10 infants in their study had hemolytic disease of the newborn. Surgical stress and inflammation are known to cause elevations of serum levels of $\mathrm{C} 3, \mathrm{C} 4$, and $\mathrm{C5}(18)$. It is possible that hemolytic disease constituted a stress in the newborns included in the study by Sawyer et al. (17) and resulted in the higher levels of complement which those authors found. It cannot be explained why Norman et al. (14) found the level of C5 in cord blood to exceed that of adults; the authors and others $(3,6,11)$ using both hemolytic and radial immunodiffusion assays have found cord blood $C 5$ levels to be lower than those in adults. Cord serum levels of properdin, C3bINA, and $\beta 1 \mathrm{H}$ have not been previously reported.

The few reports of changes in complement levels with age show more divergence than those dealing with complement levels in cord serum. The observations of Norman et al. (14) with respect to $\mathrm{C} 3$ and C4 levels agree with the authors' for ages 1-5 months but, contrary to our results, they found C5 levels to always be within the adult range. Also, contrary to these results and those of Norman et al. (14), Fireman et al. (6) found C3 levels to rise to within the adult normal range between 3-6 months of age. These data would indicate that they are well below the adult range at this age.

The postnatal changes in serum complement levels were more extensively studied for properdin and Clq (Figs. 1 and 2). The finding of the authors' that mean serum properdin levels remained at more than $2 \mathrm{SD}$ below the adult mean for the first 4 months of life and reached adult levels only at age 16-24 months emphasizes the importance of using age related values in interpreting serum complement levels in infancy (10). Complement values in the 1 st yr of life may be below the adult normal range without being indicative of complement activation. It is possible that the low serum complement levels contribute to the increased susceptibility of infants to infection. However, the in vivo significance of these low levels remains unknown. 


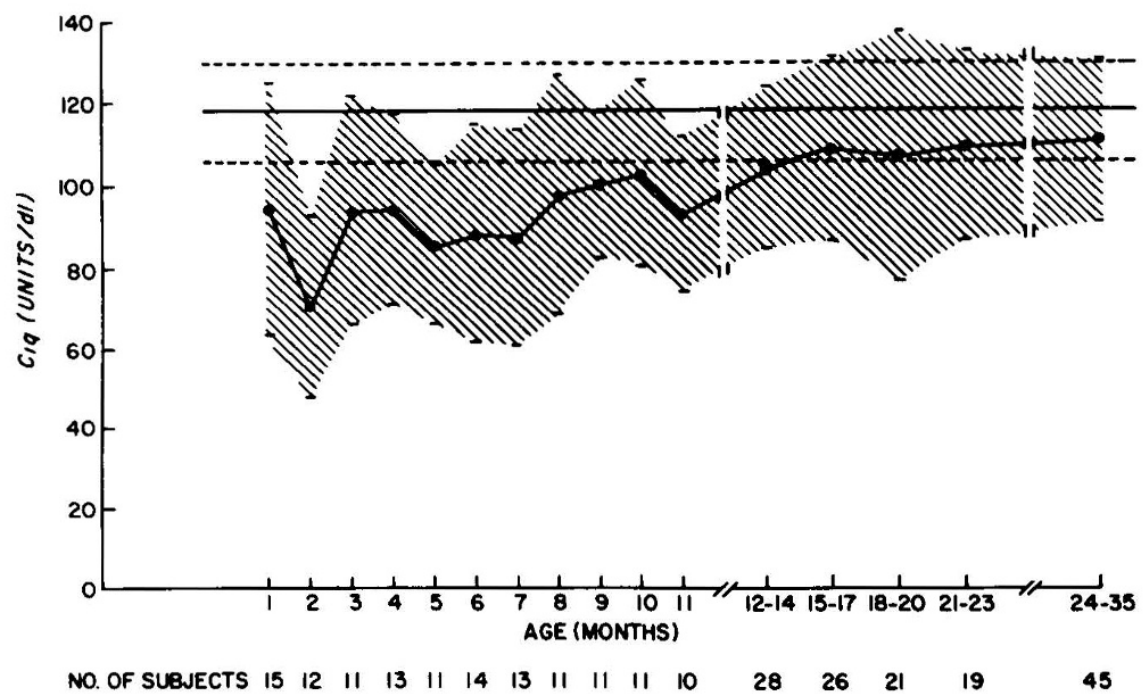

Fig. 1. Clq levels in infants ages 1-35 months. THe solid dark line represents the mean and the shaded areas \pm 1 SD. The mean adult Clq level and $\pm 1 \mathrm{SD}$ are given by the horizontal solid and dotted lines, respectively. The number of subjects in each age group is listed at the bottom of the figure.

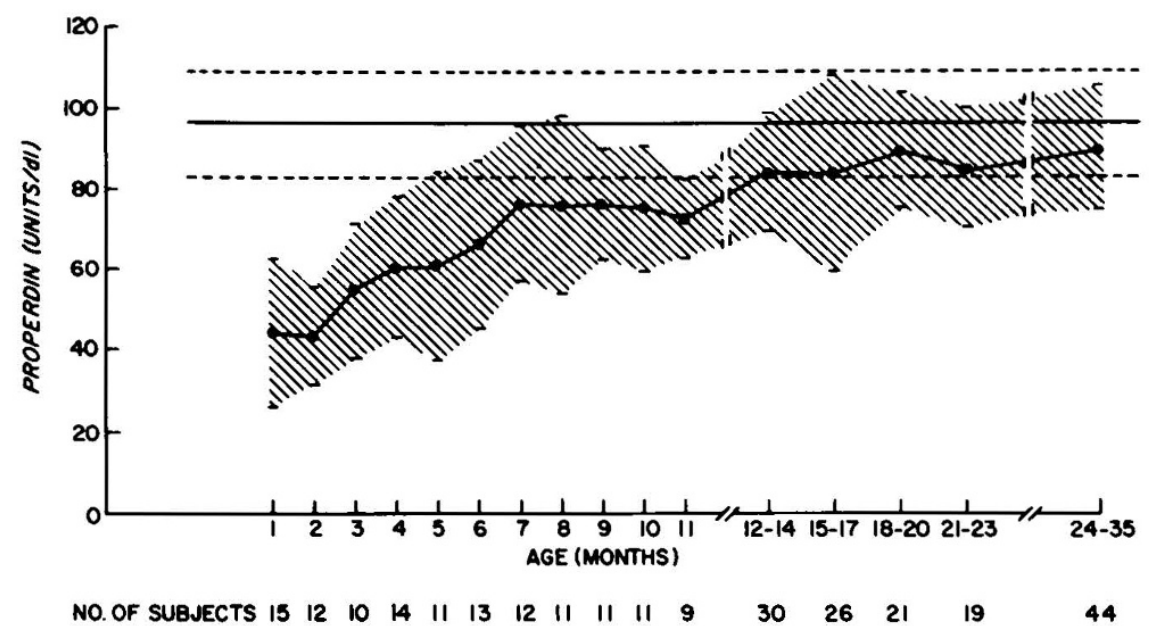

Fig. 2. Properdin levels in infants ages 1-35 months. Symbols are the same as those for Figure 1.

Table 2. Complement levels in cord serum as compared to normal adult levels ${ }^{1}$

\begin{tabular}{|c|c|c|c|c|c|c|c|c|}
\hline & $\begin{array}{c}\text { Present } \\
\text { study }\end{array}$ & $\begin{array}{c}\text { Ballow } \\
\text { et al. (3) }\end{array}$ & $\begin{array}{c}\text { Feinstein } \\
\text { and } \\
\text { Kaplan (5) }\end{array}$ & $\begin{array}{l}\text { Fireman } \\
\text { et al. (6) }\end{array}$ & $\begin{array}{c}\text { Kohler } \\
\text { (11) }\end{array}$ & $\begin{array}{l}\text { Norman } \\
\text { et al. (14) }\end{array}$ & $\begin{array}{c}\text { Sawyer } \\
\text { et al. (17) }\end{array}$ & $\begin{array}{c}\text { Stossel } \\
\text { et al. (19) }\end{array}$ \\
\hline $\mathrm{Cl}$ & & $\downarrow(\mathrm{H})$ & & & & & & \\
\hline $\mathrm{Clq}$ & $\downarrow$ (R) & $\downarrow(\mathrm{R})$ & & & $\downarrow(H \& R)$ & & $=(\mathrm{R})$ & \\
\hline $\mathrm{C} 2$ & $\downarrow(\mathrm{R})$ & $\downarrow(\mathrm{H})$ & & & & & $=(\mathrm{H})$ & \\
\hline $\mathrm{C} 3$ & $\downarrow(\mathrm{R})$ & $\downarrow(\mathrm{H})$ & $\downarrow(\mathrm{R})$ & $\downarrow(R)$ & $\downarrow(H \& R)$ & $\downarrow$ (R) & $=(\mathbf{R})$ & $\downarrow(E)$ \\
\hline $\mathrm{C} 4$ & $\downarrow(\mathrm{R})$ & $\downarrow(\mathrm{H})$ & & $\downarrow(R)$ & $\downarrow(H \& R)$ & $\downarrow$ (R) & $\uparrow(\mathbf{H} \& \mathbf{R})$ & \\
\hline $\mathrm{C} 5$ & $\downarrow(\mathrm{R})$ & $\downarrow(\mathrm{H})$ & & $\downarrow(\mathrm{R})$ & $\downarrow(H \& R)$ & $\uparrow(\mathbf{R})$ & & \\
\hline C6 & $\downarrow(\mathbf{R})$ & $\downarrow(H)$ & & & & & & \\
\hline C7 & & $\downarrow(\mathrm{H})$ & & & & & & \\
\hline $\mathrm{C} 8$ & & $\downarrow(\mathrm{H})$ & & & & & & \\
\hline C9 & & $\downarrow(\mathrm{H})$ & & & & & & \\
\hline Factor B & $\downarrow(\mathbf{R})$ & & $\downarrow$ (R) & & & & & sl $\cdot \downarrow(E)$ \\
\hline Properdin & $\downarrow(\mathbf{R})$ & & & & & & & \\
\hline C3bINA & $\downarrow(R)$ & & & & & & & \\
\hline$\beta \mathrm{lH}$ & $\downarrow(R)$ & & & & & & & \\
\hline $\mathrm{CH}_{50}$ & & & & $\downarrow(\mathrm{H})$ & $\downarrow(\mathrm{H})$ & $=(H)$ & $=(\mathbf{H})$ & \\
\hline
\end{tabular}

'Abbreviations: H, hemolytic assay; R, radial immunodiffusion; E, electroimmunoassay; $\downarrow$, levels reduced as compared to adult; $\uparrow$, levels increased as compared to adult; $=$, levels equal to that of adult.

Although the changes in mean Clq levels were not dissimilar to those of other complement components studied, the concentration of this component was much more variable than that in adults. Gewurz et al. (8) also reported a wider range of Clq values in children aged 1-16 yr than in adults. The wide range was apparent in the present data in both the retrospectively and prospectively obtained specimens. Thus, it is difficult to attribute it to acute phase reactions in patients in the retrospective study. Furthermore, 
the observations of Shutte et al. (18) indicate that, with surgical stress and inflammation, there is little change in the levels of either Clq or properdin.

In their study of Clq levels in individuals with decreased IgG synthesis, Kohler and Müller-Eberhard (12) found a correlation coefficient $(r=0.395, P<0.01)$ between serum IgG and Clq levels similar to that found in the 2 -yr-old infants in the present study $(r=0.312, P<0.05)$. In a later study, these same authors (13) found that, with low IgG levels, Clq was reduced because of increased catabolism rather than decreased synthesis, but they could not exclude the possibility that Clq synthesis was decreased in certain individuals with agammaglobulinemia syndromes (8). IgG levels in early infancy reflect both transplacentally acquired maternal IgG and $\mathrm{IgG}$ synthesized by the infant. If the serum Clq level in infancy is dependent upon the serum IgG level, then a correlation should exist between IgG and Clq levels throughout infancy. If, on the other hand, Clq and IgG synthesis are related, Clq levels would not correlate with IgG levels as long as significant amounts of maternal $\mathrm{lgG}$ circulate. The results of the authors show that $\mathrm{Clq}$ levels correlate least well with IgG levels in early infancy, when the contribution of maternal IgG to the total IgG is greatest. In infants over 10 months of age, with minimal amounts of maternal IgG, correlation coefficients between IgG and Clq were significant. The data for early infancy suggest that the serum level of IgG is not a determinant of the Clq level. The improvement in correlation as maternal IgG leaves the circulation suggests that the rate of synthesis of $\mathrm{IgG}$ is a strong influence on the Clq level.

\section{REFERENCES AND NOTES}

1. Agnello, V.: Complement deficiency states. Medicine, 57: I (1978).

2. Austen, K. F.: Inborn and acquired abnormalities of the complement system of man. Hopkins Med., J., 128: 57 (1971).

3. Ballow, M. Fang. F. Good, R. A., and Day, N. K.: Development aspects of complement components in the newborn: The presence of complement components and $\mathrm{C} 3$ proactivator (properdin factor B) in human colostrum. Clin. Exptl. Immunol., 18: 257 (1974).

4. Davis, N. C., and Ho, M.: Quantitation of immunoglobulins. In: N. R. Rose and H. Friedman: Manual of Clinical Immunology. p. 4 (Washington, D.C., American Society for Microbiology, 1976).
5. Feinstein, P. A., and Kaplan, S. R.: The alternate pathway of complement activation in the neonate. Pediatr. Res., 9: 803 (1975).

6. Fireman, P., Zuchowski, D. A., and Taylor, P. M.: Development of human complement system. J. Immunol., 103: 25 (1969).

7. Forristal, J., litaka, K., Vallota, E. H., and West, C. D.: Correlations between serum factor B and C3b inactivator levels in normal subjects and in patients with infections, nephrosis and hypocomplementemic glomerulonephritis. Clin. Exptl. Immunol., 28: 61 (1977).

8. Gewurz, H.. Pickering, R. J., Christian. C. L., Snyderman, R., Mergenhagen, S. E., and Good, R. A.: Decreased Clq protein concentration and agglutinating activity in agammaglobulinemia syndromes: an inborn error reflected in the complement system. Clin. Exptl. Immunol., 3: 437 (1968).

9. Johnston. R. B., and Stroud, R. M.: Complement and host defense against infection. J. Pediatr., 90: 169 (1977).

10. Kim, Y., Miller, K., and Michael, A. F.: Breakdown products of $\mathrm{C} 3$ and factor B in hemolytic-uremic syndrome. J. Lab. Clin. Med., 89: 845 (1977).

11. Kohler, P. F.: Quantitative comparison of complement in the mother and newborn. Fed. Proc., 27: 491 (1968).

12. Kohler, P. F., and Müller-Eberhard, H. J.: Complement-immunoglobulin relation: Deficiency of $\mathrm{Clq}$ associated with impaired immunoglobulin $\mathrm{G}$ synthesis. Science, 163: 174 (1969).

13. Kohler, P. F., and Müller-Eberhard, H. J.: Metabolism of human Clq: Studies in hypogammaglobulinemia, myeloma, and systemic lupus erythematosis. J. Clin. Invest., 51: 868 (1972).

14. Norman, M. E., Gall, E. P., Taylor, A., Laster, L., and Nilsson, U. R.: Serum complement profiles in infants and children. J. Pediatr., 87: 912 (1975).

15. Ooi, Y. M., Vallota, E. H., and West. C. D.: Classical complement activation in membranoproliferative glomerulonephritis. Kidney Int., 9: 46 (1976).

16. Ruddy, S., Gigli, I., and Austen, F. K.: The complement system of man. N. Engl. J. Med., 287: 489 (1972).

17. Sawyer, M. K., Forman, M. L., Kuplic, L.S., and Stiehm, E. R.: Developmental aspects of the human complement system. Biol. Neonate, 19: 148 (1971).

18. Schutte, M., DiCamelli, R., Murphy, P., Sadove, M., and Gewurz, H.: Effects of anesthesia, surgery, and inflammation upon host defense mechanisms: I. Effects upon the complement system. Int. Arch. Allergy Appl. Immunol., 48: 706 (1975)

19. Stossel, T. P., Alper, C. A., and Rosen. F. S.: Opsonic activity in the newborn: role of properdin. Pediatrics, 52: 134 (1973).

20. Strife, C. F., McDonald, B. M., Ruley, E. F., McAdams, A. F., and West, C. D. Shunt nephritis: the nature of the serum cryoglobulins and their relation to the complement profile. J. Pediatr., 88: 403 (1976).

21. This research was supported in part, by National Research Service Award IT-32AM 07051 from the National Institute of Arthritis, Metabolism, and Digestive Diseases: United States Public Health Service (C. A. D.).

22. Requests for reprints should be addressed to: Charles A. Davis, M. D., Rainbow Babies and Childrens Hospital, 2101 Adelbert Road, Cleveland, OH 44106 (USA).

23. Received for publication July $25,1977$.

24. Accepted for publication September $26,1978$. 